\title{
The Marshall Plan
}

\author{
Jacob Magid \\ History Department, Boston University, Boston, USA \\ Email: jacobmagid@gmail.com
}

Received November $18^{\text {th }}$, 2012; revised December 15 ${ }^{\text {th }}$, 2012; accepted December $26^{\text {th }}$, 2012

\begin{abstract}
This paper discusses the European Marshall Plan in three subsections: the impetus for its creation, its logistical implementation, and the results to both Europe as a whole and the United States. The consequences of the Marshall Plan are further broken down into three pieces: direct economic effects, indirect economic effects, and political effects. I argue that there is little evidence that direct economic effects account for the Marshall Plan's success. Instead, the indirect economic effects, particularly in the implementation of liberal capitalistic policies, and the political effects, particularly the ideal of European integration and government-business partnerships, are the major reasons for Europe's unsurpassed growth.
\end{abstract}

Keywords: Marshall Plan; Cold War; Economics; Aid

\section{Post WWII Europe and the Need for Aid}

World War II ranks as one of the most destructive events in the history of Europe. ${ }^{1}$ Along with the tens of millions who died, the War uprooted millions more and devastated the entire European business structure. The international division of labor that had existed before the war, where Europe shipped finished goods to the Americas, Asia, and Africa in return for foodstuffs and raw materials, virtually vanished. Many overseas holdings by European countries were sold off to pay for war imports. As the war wound down, currency and gold deposits were used to purchase relief material, leaving little for capital formation and long-term reconstruction. All told, Europe's capacity for imports was reduced to $40 \%$ of its prewar levels (De Long \& Eichengreen, 1991). Additionally, many assumed the US would withdraw from Europe into isolationism as it had done after WWI: lend-lease ended immediately after the Japanese surrender, Truman's internationalist Democratic administration was weak, and Congress was increasingly calling for balanced budgets.

To cope with the massive need for aid, the newly-formed United Nations created the United Nations Relief and Rehabilitation Administration (UNRRA) which served to deliver food, clothing, medical supplies, and other necessities. UNRRA was an ad hoc program that could be discontinued at any time and, thus, impeded the planning necessary for reconstruction. To address this problem, the UN created the International Bank for Reconstruction and Development (IBRD). After reconstruction, the International Trade Organization (ITO) and the International Monetary Fund (IMF), created at Bretton Woods, would step in to normalize economic policies and short-term funding.

\section{The Rise of Unilateral Aid}

Yet very quickly this multilateral approach for aid and reconstruction fell apart. The amount of aid, its terms, and the speed at which it was delivered were critically failing. In the

\footnotetext{
${ }^{1}$ This paper will deal exclusively with the effects of the Marshall Plan in Europe and the United States; the Marshall Plan for Japan and China will not be discussed.
}

summer of 1945, as a stopgap measure until the IBRD could be formed, the United States Export-Import Bank increased its capital from $\$ 750$ million to $\$ 3.75$ billion (Kindleberger, 1968). ${ }^{2}$ The US was already giving unilateral aid directly through the Government Relief in Occupied Areas (GARIOA) program which, between July 1945 and 1947 amounted to \$13 billion. Additionally, the United Kingdom, which benefitted from its "special relationship" with the United States, received a $\$ 3.75$ billion loan under the Anglo-American Financial Agreement of 1946 (Crafts, 2011).

Tensions with the Soviets only made matters worse. The friction began over the treatment of Germany, before the war had even ended. The Western allies wanted Germany punished but also to play a key role in European recovery and regain a stable economy. The Soviets, on the other hand, wanted Germany permanently weak. Since they bore a disproportionate burden in terms of deaths and damages during the war, the Soviets also demanded reparations, much as they had after WWI. When the Western powers dragged their feet, the Soviets looted their part of occupied Germany, sending machinery and equipment back to Russia as "war prizes." In an attempt to compromise, the Western allies agreed to hand over to the Soviets all capital stock in their occupied zones that was above the amount deemed necessary to maintain a standard of living no greater than the average of Germany's surrounding countries. The Soviets, however, began to replace capital machinery reparations with current production output reparations, in clear violation of the Potsdam Agreement; the Soviet appetite for second-hand capital stock was quickly diminishing. This prompted General Clay, the Military Governor of the US-controlled West German occupied zones, to stop sending reparations to Russia (Kindleberger, 1968).

The discord only continued to intensify. After much political wrangling over the role of centralized planning versus free market allocation, the Soviet Union refused to join the IMF or the IBRD. As for the UNRRA, the Soviet Union was techni-

\footnotetext{
${ }^{2}$ Originally, a third of this increase was earmarked for the Soviet Union but, for a variety of reasons stemming mainly from the increasing hostilities between the two superpowers, was never actually transferred.
} 
cally listed as a donor but fought hard to allow Ukraine and Belorussia to function as net recipients. At the same time, Canada, another donor, decided not to participate while the UK wriggled out of most of its commitments because of military relief obligations to Austria and Italy. What's more, the US was concerned that funds being sent to Eastern European countries were being illicitly used to bolster Communist parties. All told, the US bore $3 / 4$ of the costs yet held only 1 of 17 votes regarding UNRRA's management (Kindleberger, 1968).

As the Soviets began to turn away from multilateral aid and reconstruction, the calls for more US assistance grew louder. The European winter of 1946-7 was one of the worst in recorded history with heavy snowfalls and low temperatures shutting down transportation throughout northern and western Europe and destroying the winter wheat. Yet even before the devastating winter and subsequent dry spring, French, German, Belgian, and Italian harvests were still only half of pre-war levels in 1945-6 (De Long \& Eichengreen, 1991)! Governments tried to cope with low food supplies by enforcing low price ceilings which, coupled with high inflation and taxation, discouraged farmers from bringing their produce to market. Even after accounting for all the deaths due to the war, the population in Europe had increased by $10 \%$ while only possessing $80 \%$ of the food supply (De Long \& Eichengreen, 1991).

As Europeans increasingly relied on agricultural imports from the US, their gold and dollar reserves began to dwindle: Europe had a current account balance deficit of $\$ 9$ billion a year in 1946 (Crafts, 2011). Simply put, European exports were too low to finance the necessary imports. Private capital was unwilling to lend to Europe because of the poor returns, outsized default rates, and rampant inflation experienced after WWI. Domestic taxes were unable to balance budgets or pay for relief. Inflation hampered business planning as well as efforts to accelerate reconstruction. Both the IBRD and IMF were stretched to their limits and unable to provide any more aid. By 1947, German coal production was still only about half of its pre-war level. In other countries, like Britain and Belgium, coal production was down $10 \%$ - 20\% from 1938 levels (De Long \& Eichengreen, 1991). Because of the cold winter, much of the coal that was still available was diverted to heating, increasing the coal shortage for industrial purposes. In fact, by the end of the year, Western European industrial production was still only $88 \%$ of its pre-war levels (Hogan, 1987).

Europe's outlook was dim. Wartime controls had created a habit of government involvement in market mechanisms; the Soviet's had great success during the war in churning out machinery and equipment as well as high reported growth rates. This left many convinced that centrally planned economies were the way of the future, especially in the aftermath of the Great Depression.

\section{America Steps In}

As a result of these domestic crises, Britain began backing out of its commitments in Greece, Turkey, and its occupation zone in West Germany. While American and British occupation zones were relatively easily merged under US military jurisdiction, financial support for Greece required congressional approval. By February 1947, the British had formally asked the US to take over their commitments in both Greece and Turkey. On March 12, 1947, President Truman addressed Congress, calling for economic support for both these two countries under the auspices of helping them in their struggles against Communism. He then broadened his foreign policy to what is now referred to as the Truman Doctrine:

I believe that it must be the policy of the United States to support free peoples who are resisting attempted subjugation by armed minorities or by outside pressures. I believe that we must assist free peoples to work out their own destinies in their own way. I believe that our help should be primarily through economic and financial aid which is essential to economic stability and orderly political processes $\cdots$ This is an investment in world freedom and world peace (Truman, 1947).

Following this speech, a formal aid strategy applying the Truman Doctrine began to be developed under the Secretary of State's newly formed Policy Planning Staff; political, military, and, above all, economic aid would be used to contain Communism. By May 23, 1947, they had published a proposal for a three-part strategy: first, the American people must be informed of the poor economic conditions in Europe, second, a shortterm solution would be implemented to relieve bottlenecked industries, particularly coal production in the Rhine Valley, and third, a comprehensive long-term rehabilitation plan would be created. If Eastern European countries or the Soviets wished to partake, they would be forced to institute democratic and capitalist practices. Otherwise, aid would be limited to Western Europe. This policy prescription marked the beginnings of the European Recovery Program (ERP) (Mallalieu, 1958).

Utilizing his reputation as the architect of military victory in WWII, Secretary of State George C. Marshall became the face of, and lent his name to, this bold initiative. On June 5, 1947, he delivered his now-famous speech at Harvard University introducing unilateral aid to Europe:

The truth of the matter is that Europe's requirements for the next three or four years of foreign food and other essential products-principally from America-are so much greater than her present ability to pay that she must have substantial additional help or face economic, social, and political deterioration of a very grave character $\cdots$ The remedy lies in restoring the confidence of the European people in the economic future of their own countries and of Europe as a whole $\cdots$ It is logical that the United States should assist in the return of normal economic health in the world, without which there can be no political stability and no assured peace (Marshall, 1947).

\section{The Marshall Plan Takes Shape}

The State Department insisted that Europeans themselves shape the details of the program in order to avoid firm commitments before Congress officially approved. As a result, a Tripartite Conference was held in late June 1947 between France, England and the Soviet Union with no direct American representatives. The Soviet Union objected to any conditionality of the aid (the capitalist and democratic reforms mentioned in the Policy Planning Staff's proposal) as an infringement on national sovereignty. There was initial anxiety that the Soviet Union would accept the aid and, consequently, make the costs to the US prohibitively expensive, both financially and politically. The greater concern, however, was that the Soviet 
Union would agree to the plan and, much like with the UNRRA, disrupt its workings from within. Instead, the Soviets simply pulled out of the conference and refused to participate. To this day, theories abound as to why the Soviets did not choose to sabotage the Marshall Plan from within; general ineptness of Soviet foreign policy, distraction caused by other pressing matters such as political centralization in Eastern European countries, or, most likely of all, a Soviet fear that any infiltration of their bloc by Western influences would only further destabilize their precarious political hold (Mallalieu, 1958).

After the Tripartite Conference, France and England extended invitations to twenty-two other European countries (excluding only Spain and the Soviet Union) to discuss Marshall's proposal. Under pressure from Moscow, all the Eastern European countries refused to attend. Ultimately, diplomats from sixteen nations convened in Paris on July 12th to establish the Committee for European Economic Cooperation (CEEC): Austria, Belgium, Denmark, France, Greece, Holland, Iceland, Ireland, Italy, Luxemburg, Norway, Portugal, Sweden, Switzerland, Turkey, and the UK. Despite French concerns, the State Department was adamant about including Germany in the aid plan because, as the major occupying power, West Germany's utter destruction at the end of WWII accounted for a serious drain on US resources (Hogan, 1987).

The proposed plan was designed for four years and was an amalgamation of estimates for resources and credits from each of the participating nations, originally totaling $\$ 29.2$ billion. By mid-August 1947, the Conference members needed explicit guidance from the US to make their plans more detailed and increase the likelihood that Congress would approve. The State department sent George Kennan (Chief of the Policy Planning Staff and founder of the Theory of Containment) and Charles Bonesteel (special assistant to the Secretary of State) to advise the CEEC on the necessary conditions of the aid: financial stability, reduction in trade barriers, and a centralized organization to administer the program. The goals of the aid package were also outlined: increase European production, expand Europe's foreign trade, contain inflation, and develop regional economic cooperation as well as rehabilitate the German economy.

\section{Congress and Popular Support}

The proposal was sent to the State Department on September 22 and, after some edits, including a reduction in the requested amount to $\$ 17$ billion, was passed on to Congress for approval (Hogan, 1987). Congressional debate on the Marshall Plan began in January of 1948. Proponents claimed the ERP would be a bulwark against Communism, maintain domestic prosperity and exports, and serve as a sign of American charity. Opponents claimed it was too costly, would be ineffective against Communism, and was tantamount to American Imperialism (Hitchens, 1968).

After such a grueling war, most Americans were apathetic of foreign policy in general and the Marshall Plan in particular. Though polls measuring public opinion were generally inaccurate, congressmen relied heavily on them as measures of support for the ERP. The majority of people who had heard of the plan, however, were in favor of it: farmers supported it by $60 \%$ and businesses supported it by over 70\% (Hitchens, 1968). ${ }^{3}$

The Committee for the Marshall Plan (CMP) had already

${ }^{3}$ Some estimates say up to $75 \%$ of the American public had no knowledge of the Marshall Plan. begun organizing in autumn of 1947 to drum up support in preparation of the vote. The CMP operated by fostering positive newspaper sentiment (such as with Walter Lippmann), running advertisements, sponsoring speakers' bureaus, and funding radio broadcasts. They also targeted special interest groups directly to garner their support. In fact, the CMP managed to achieve a rare feat: Congressmen actually received petitions from large numbers of people for a proposed law that would effectively raise their taxes.

Congressmen who opposed the Marshall Plan and were up for reelection in 1948 suffered huge losses. Though Republicans tended to oppose the Foreign Assistance Act, the bill which would enact the ERP, it was generally a bipartisan effort due to the strong alliance between President Truman, a Democrat, and an influential Republican Senator from Michigan, Arthur Vandenberg: Republicans succeeded in removing commitments for specific dollar amounts of aid and ensured that the ERP would not be administered by the State Department. Limiting the aid plan to Europe, which possessed the institutions necessary for and experiences dealing with market economies, as well as keeping the timeframe to a constrained four years helped push the Foreign Assistance Act through Congress. The real tipping point, however, was the coup in Czechoslovakia in February 1948 which solidified political will against a rising tide of Communism. In the end, the Marshall Plan was instituted because Europe's recovery was considered essential to the long-term interests of the United States (Hogan, 1987).

The bill was signed into law on April 3, 1948 and placed under the control of the European Cooperation Agency (ECA), the newly-formed bureau responsible for the Marshall Plan's execution. This agency would be politically independent and staffed with businessmen and managers from the private sector such as Paul Hoffman, the former president of Studebaker and the newly appointed Administrator of the ECA. Hoffman had cabinet status and would report directly to the President. This would allow the ECA to steer a course between the public priorities of relief and Communist containment and the private means of achieving these goals, including monetary stabilization, trade liberalization, economic integration, and industrial productivity (Hogan, 1987). Subsequently, the CEEC formed the Organization for European Economic Cooperation (OEEC, now known as the OECD) to allocate the distribution of aid and continue their efforts for regional economic integration (Mallalieu, 1958).

\section{Implementation of the Marshall Plan}

The OEEC would work with each Marshall Plan country as well as an ECA officer to determine exactly what supplies would be needed from the US; for West Germany, requests were first sent through the US Army. The OEEC and ECA officer would coordinate these needs between all the affected nations and ensure that goods coming from the US could not be accessed from alternative sources; in fact, only a third of the goods transferred in the ERP actually came from the US, totaling approximately $1 \%$ of her gross national product (Crafts, 2011). Much of the remaining material was transferred either through trade amongst the Marshall Plan countries themselves or from South America. This list of goods was adjusted continually over the course of the Marshall Plan as the needs of European recovery changed. The list included both materials in short supply in the US, like scrap metals and fertilizer, as well 
as those in surplus, such as cotton, fruits, and tobacco. Few consumer goods were sent. The ECA officer would then pass along a list of the requested materials to Hoffman in Washington DC. Hoffman and his staff would then work with the National Advisory Council on International Monetary and Financial Problems (comprised of the secretaries of the Treasury, State and Commerce, the Federal Reserve Board chairman, and the head of the Export-Import Bank) as well as the Commerce and Agriculture Departments, Interior Department, and any applicable industry advisory committees and trade organizations to determine how much could be sent (without creating an undue disruption in American production) and if the aid should be given as a grant or loan. The White House acted as the final arbiter in cases of disputes amongst these various interests. Hoffman would then send word to the ECA officer overseas and the procurement process would begin.

In most cases, US businessmen would market their goods directly to foreign firms, utilizing the ECA office in Washington, foreign businessmen, foreign governments, their applicable trade associations, or the export-license office in the Department of Commerce. Businesses, however, were still reluctant to engage in foreign direct investment in Europe as they feared that they would be unable to realize their returns in dollar denominations. The ECA, therefore, also functioned as a guarantor of convertibility from European currencies to dollars as long as these investments were considered essential for European recovery, conversion was not available by ordinary financial channels, and the returns were withdrawn within 14 years of the initial investment. The ECA, however, did not guarantee against ordinary conversion or investment risks.

Hence, while government controls ensured the goods provided were essential for European recovery, checked transacttions through post-auditing, and maintained the export licenses required to actually send the supplies overseas, private enterprise was allowed to function normally within those parameters. There were, however, some important exceptions. Export licenses could be revoked if the terms of the business arrangement were not approved by the ECA (e.g. in the case of price gouging). Additionally, some industries, particularly in fertilizers which had no interest in expanding into Europe, were forced to export a certain percentage of their output when the amount agreed upon through private means was insufficient (Gubin, 1948).

\section{Breakdown of Aid}

US industries which had spare capacity to increase production, such as agriculture, farm machinery, machine tools, and truck manufacturing, did particularly well in the Marshall Plan. Industries which did not usually export, like coal and other mined materials, enjoyed a short-term jump in demand as European alternatives were brought up to speed. Even exporters of non-Marshall Plan goods benefitted because, as non-Plan countries received dollars for their contributions, such as those in South America, their demand for all US goods increased. Yet other industries, such as fertilizer, steel, fuel oil, and freight car manufacturing were already stretched thin. And then there were other industries, such as textiles, electrical generation machinery, and timber products which were not much effected at all. US consumers enjoyed lower unemployment rates as well as an increase in European goods like perfume and lace. On the other side of the coin, domestic prices remained higher than they otherwise would have been and certain shortages, such as steel, were prolonged (Gubin, 1948).

Total aid amounted to $\$ 13.2$ billion. The dollars, however, were never actually transferred out of the United States; they were instead used to pay for the real goods that were then exported to Europe. $60 \%$ went to food, feed, fertilizer, industrial materials and semi-finished goods, $16 \%$ went to fuel, and another $16 \%$ went to machinery and vehicles. The remaining $8 \%$ were the costs associated with using the merchant marines instead of lower cost alternatives, an earmarked concession which helped ease the ERP through Congress (De Long \& Eichengreen, 1991).

The aid was split between grants $(60 \%-80 \%)$ and loans (20\% - 40\%) depending on each country's ability to repay (Gubin, 1948). The actual amount allocated to each country was based on the dollar value of their balance of payments deficits as determined by the OEEC. Each country was then required to deposit an equivalent amount of their domestic currency into a Counterpart Fund overseen by the ECA. This Counterpart Fund could only be used for purposes fostering reconstruction: for instance, in the UK, these internal funds were used to reduce public debt and, therefore, inflation. Part of the aid package, approximately $\$ 300$ million, included a productivity assistance program which allowed Europeans to tour American firms and receive technical services and training (Crafts, 2011).

The ECA was also very active in pressuring European governments to institute free market policies; they leveraged their authority to ensure structural reforms were implemented in keeping with the American conditionality of economic integration and trade liberalization. The particular reforms for each country varied drastically. For instance, in France, the EPA refused to release Counterpart Funds until the government committed to balancing the budget but, in Italy, they pressured the government to underwrite programs for more public investment (Hogan, 1987). Aid money could also be reduced; the UK lost their aid for timber imports after its government began constructing public housing and continued to nationalize its steel industry (De Long \& Eichengreen, 1991). All participating countries were also required to sign bilateral agreements with the US committing them to financial stability, balanced budgets, realistic exchange rates, reduced quotas and tariffs, and most-favored-nation treatment for West Germany. ${ }^{4}$ To foster regional economic cooperation, the OEEC earmarked $\$ 1.5$ billion for the creation the European Payments Union (EPU). Though the EPU was not officially implemented until 1950, it was a major step in smoothing international trade (Crafts, 2011). ${ }^{5}$ These policies, however, did not simply recreate America's version of free markets; European governments maintained much of their controls on business, especially in utilities and heavy industry, and they also created the largest safety nets and social insurance programs in history.

\section{Effects of the Marshall Plan}

The results of the Marshall Plan were astounding. It took

\footnotetext{
${ }^{4}$ Most-favored nation treatment meant that governments would not institute punitive trade policies against West Germany.

${ }^{5}$ Since US tender was the only stable reserve currency at the time, all international trade was done using dollars. With a shortage of American money, the EPU accounted for all trade but saved the actual transfer of currency until the end of the month. This accounting practice improved liquidity and made trade much easier.
} 
Europe only four years to reach pre-war levels of output and to stabilize prices. In contrast, after WWI, France suffered from hyperinflation for eight years and Germany's struggles infamously led to the fall of the Weimar Republic and the rise of National Socialism. Western European output increased 32\%, agricultural output increased $11 \%$, and industrial output increased 40\% (Hogan, 1987). Stories of Marshall Plan goods and practices saving businesses abounded: at the Doboelman soap works in Holland, American experts trained the Dutch in new machinery that cut processing time from five days to two hours. In Norway, fishermen used new nets made from yarn spun in Italy. In Offenbach in West Germany, Marshall Plan leather revived the handbag industry. In Lille, Marshall Plan coal kept a steel factory in business. In Roubaix, Marshall Plan wood maintained one of the world's largest textile mills. In 1945, only twenty-five thousand tractors were in use on French farms but, only four years later, another two hundred thousand tractors were in the fields (Duignan \& Gann, 1997). Furthermore, the Marshall Plan heralded in an era of unsurpassed prosperity for Europe: a twenty year period between 1953 and 1973, paralleling America's Golden Age, with no significant economic downturns and $4.8 \%$ annual growth rates, more than twice as high as any other point in history. Investment rates were also twice as high as before WWII (De Long \& Eichengreen, 1991).

\section{Direct Economic Effects}

Yet the question remains: was this economic success due to the Marshall Plan? In fact, many scholars and economists argue that Europe's outlook in the medium term was already bright; they already had longstanding capitalist traditions and relatively successful market economies. With their friendly relations to the US, firms in Europe seemed set to catch up with their American counterparts simply with transfers in technology and innovation. Although not strictly measured, rule of law, control of corruption, regulatory quality, and government effectiveness were also deemed much higher in Europe than most other parts of the world. Indeed, when one looks at the direct implications of the Marshall Plan, the evidence suggests a particularly minor role for the aid (Crafts, 2011).

The total amount of aid, $\$ 13.2$ billion, only comprised 3\% of total Western European output (for a country-by-country breakdown, see Table 1).

Table 1.

Breakdown of aid by country. ${ }^{6}$

\begin{tabular}{ccc}
\hline & \$ Million & \% GDP \\
\hline United Kingdom & $\$ 2826.0$ & $1.8 \%$ \\
France & $\$ 2444.8$ & $2.2 \%$ \\
Italy & $\$ 1315.7$ & $2.3 \%$ \\
West Germany & $\$ 1297.3$ & $1.5 \%$ \\
Netherlands & $\$ 877.2$ & $4.0 \%$ \\
Austria & $\$ 560.8$ & $5.7 \%$ \\
Belgium \& Luxembourg & $\$ 546.6$ & $2.2 \%$ \\
Denmark & $\$ 257.4$ & $2.2 \%$ \\
Norway & $\$ 236.7$ & $2.5 \%$ \\
Sweden & $\$ 118.5$ & $0.4 \%$ \\
\hline
\end{tabular}

${ }^{6}$ Crafts, 2011.
Based on the standard Solow Growth Model and an average direct effect of a $2 \%$ boost to GDP, aid would only have increased the growth rate by about 0.3 percentage points. In fact, the dollar amount was really no larger than the UNRRA aid that had preceded it. Moreover, there is no correlation between the amount of aid received and the speed of the recovery: both France and the UK received more aid, but West Germany recovered significantly faster (De Long \& Eichengreen, 1991).

In terms of direct changes to investment, only $16 \%$ of the total amount of aid was used to boost the current capital stock like machinery and vehicles. Contemporary estimates suggest that for every dollar of aid money 65 cents went to increase current production and only 35 cents went to investment. Since investment at that time was yielding 50\% due to the low existing capital stock, every dollar spent towards investment added 50 cents towards output in the following year. Using basic growth accounting, this means that the investment effect of Marshall Plan aid only added half a percentage point to the growth rate. Over the four-year span of the ERP, that means that the investment effect increased total Western European output by only about 2\% (De Long \& Eichengreen, 1991).

Other direct effects were similarly paltry. Infrastructure was relatively easy to repair and, by 1946, had already mostly returned to pre-war levels. Even bottlenecked production, most famously with coal, is insufficient to explain the rapid economic growth after the Marshall Plan. Since coal imports were only $7 \%$ of the Marshall Plan and would have effected only industrial production and transportation, together accounting for about half of total output, this bottleneck could have, with even the most generous assumptions, accounted for only 3 percentage points of the total increase in output. Even though the ERP, unlike UNRRA, allowed businesses and governments to plan more effectively thanks to its set time period and clear conditions, the direct effects of the Marshall Plan, through boosts to production, investment, infrastructure, and bottlenecks, cannot explain the extraordinary economic growth from 1948-1973. Thus, if we were only to look at these direct effects, we could conceivably conclude that European economic success was almost completely unaffected by the ERP (De Long \& Eichengreen, 1991).

\section{Indirect Economic Effects}

Direct economic effects of the Marshall Plan, however, comprise only one of three consequences of the aid in Europe's recovery: direct economic impact, indirect economic impact, and political impact.

The indirect economic effects of the Marshall Plan, though more difficult to quantify, profoundly impacted Western Europe by altering its underlying institutions. First and foremost, the ERP changed the tone of economic policy. Fearing a return to the Great Depression and seeing the supposed economic success of the USSR, there were loud calls to continue wartime controls of key resources by rationing foreign exchange and imposing price controls. Most European countries at the time were still nervous to trust markets and relied heavily on regulation, government control, and other tariffs and trade barriers.

Argentina's poor growth after WWII provides a compelling example of how Europe may have gone had it continued to follow these policies. Argentina had been considered a firstworld country with high growth rates prior to WWII. Her fall from grace into stagnation and economic decline warrants a 
research paper in and of itself, but, to summarize, was due to economic policies which had the government first determine the allocation of goods and then allow the market to distribute income. According to Diaz Alejandro, a specialist on the subject, these damaging economic policies were implemented due to a politically active and riled industrial working class, economic nationalism, deep divisions between elites and the poorest workers, and a government habituated to controlling the allocation of goods. All of these factors were also present in Western Europe after WWII (De Long \& Eichengreen, 1991).

It was the Marshall Plan administrators and the conditionality of the aid which pushed liberal market reforms on Western Europeans. The bilateral treaties signed with each Marshall Plan country required strong macroeconomic policies and trade liberalization policies such as reduced spending by governments, necessary for financial stability, as well as lower tariffs to increase trade and a general emphasis on the market allocation of resources. Counterpart funds and ERP goods all had to be approved by the ECA which gave them the leverage for influencing domestic programs. At the same time, compared to post-WWI reconstruction when deflationary policies were strictly enforced to maintain gold standard parity, post-WWII policies were much more flexible. The Europeans themselves would not have chosen these developments; they were more concerned with recreating the pre-war economic system and balance of power than integration and liberal capitalism. It took consistent pressure from the United States representatives to enforce these changes (Hogan, 1987). In other words, the Marshall Plan forced Western Europe away from centrally-planned economies. Without the active involvement of the ECA and the conditionality of the aid program, Western Europe would likely have suffered from overregulation and stagnation, like in Argentina, or financial instability, like in post-WWI Europe.

Additionally, the Marshall Plan affected total factor productivity (TFP) - intangible or difficult to quantify productivity improvements such as management practices or the incorporation of newer technologies - through the productivity assistance program. Boosts to TFP have a multiplier effect on GDP; a $1 \%$ increase in TFP leads to a greater than $1 \%$ increase in GDP. Furthermore, the added stability of the ERP, in terms of both European integration and formal eco-political support of the US, boosted confidence, a necessary factor in lifting private investment.

In Europe as well as the United States, the Marshall Plan instituted a framework of government-business partnerships that paved the way for both a more socially engaged private sector as well as a constructive public policy fostering economic growth and stability. Even before the ERP was announced, the CMP was assembling labor, farm, academic, and business leaders in support. The fact that the ECA was independently staffed by managers and businessmen instead of bureaucrats or career politicians further exemplifies this collaboration. Allowing private businesses to undertake their own transactions was another important step in combining the strategic oversight of the government with the efficiency of the market. And the strong involvement of trade organizations and industry advisory committees in ECA decisions was another.

Finally, the Marshall Plan also helped create the EPU which served to further reduce trade barriers and reintegrate West Germany into European markets. Because of an overall dollar shortage and the inconvertibility of European currencies due to underlying economic devastation, international commerce faced a liquidity crisis: the volume of trade between nations was limited to the balance of payments. ${ }^{7}$ Thus the EPU, backed by the US, served a vital role in providing a line of credit for countries in deficit. Without the EPU, balance of payment deficits would have strangled import-export markets. The EPU, which was replaced by the European Monetary Agreement in 1958, offered trade liberalization that was perhaps the single most important reason for economic growth in postwar Europe (De Long \& Eichengreen, 1991).

\section{Political Effects}

The political effects of the Marshall Plan are even more difficult to quantify. In the aftermath of WWII, European reconstruction relied on two pillars: lifting price controls and stabilizing inflation. This would incentivize producers to bring their goods to market and encourage saving, investment, and planning. To reduce inflation, budgets had to be balanced. Balancing budgets required political compromise; consumers must accept higher prices for goods, workers have to accept lower wages, firms have to reduce profit expectations, taxpayers have to accept increased liabilities, and landowners have to accept lower property values. Estimates for the net demands of these interest groups exceeded national output by $5-7$ percentage points. Therefore the 2 - 3 percentage point boost provided by the ERP aid played a significant role in minimizing the distributional tug-of-war while simultaneously serving as a cushion for wealth loss (De Long \& Eichengreen, 1991).

This new "social contract" led to higher growth, making all stakeholders better off in the long-run. Firms would restrain wages for workers but increase investment. Governments would implement welfare policies and utilize Keynesian demand control to maintain high employment. Labor unions would raise productivity and shun Communist ties. This shared sacrifice and, later, shared abundance eased class tensions, eliminating the root of domestic Communism. Yet the Marshall Plan's role in this social contract is not black and white: Sweden had institutions like this before the Marshall Plan while wages in Italy were suppressed due to the large amount of available labor, not an implicit agreement between firms, workers, and the government. In other words, though the Marshall Plan may have served as a cushion to alleviate some of the pain of reform, we cannot entirely credit it for the rise of this social contract (Crafts, 2011).

Beyond the purely economic and domestic policy implications, the Marshall Plan showcased the deep US commitment to Europe at a time when isolationist ideology was threatening to come back in force. We cannot ignore the additional benefit Europeans enjoyed from American optimism, peaceful production, consumerism, individual welfare, and profits. By pushing Europeans towards political and economic cooperation, the Marshall Plan also helped instigate a period of peace between nations that had been enemies for millennia. All of the above helped foster an intricate web of contacts among businessmen, civil servants, and even trade unionists which, along with NATO, forged an alliance that could fill the vacuum left after WWII and withstand Communism (Duignan \& Gann, 1997). This alliance preserved America's access to Europe's markets, sources of supply, manpower, and industrial capacity while simultaneously denying them to the Soviets (Hogan, 1987). In fact, the Marshall Plan's emphasis on collaboration, coordina-

\footnotetext{
${ }^{7}$ A surplus in exports would not offset a deficit in imports.
} 
tion, and collective action came to dominate the European military philosophy as well; NATO would contribute to the unification of Europe as well as boost confidence by increasing security (Hogan, 1987).

\section{Conclusion}

Thus the Marshall Plan functioned as more than just an economic stimulus package or even a structural adjustment program ingraining free market principles and institutions into Europe. Instead, this massive transfer of wealth, with no major cases of fraud or racketeering, laid the foundations for a new era: European nationalism would be limited by multinational cooperation, economies would be integrated by market forces, and both would stabilize growth and foster international solidarity. These liberal capitalist ideals tied economic freedoms to political freedoms and cultivated an ethos of free enterprise (Hogan, 1987).

The ERP was more than just the sum of its parts. Though it cannot be credited with single-handedly saving Western Europe from economic doom, it was also not a mere relief package. Along with the economic implications of the aid came structural changes and a philosophical orientation away from pure national self-interest. In combination with NATO and the Bretton Woods agreements, the Marshall Plan helped Western Europe and the US cooperate and collaborate with a multinational and mutually beneficial mentality. This unified front, tying together both economic and military integration, set the stage for the ideological (and at times, literal) battles against Communism throughout the Cold War. In their eventual triumph, the internationalism and integration of government with business, as personified in the Marshall Plan, proved to be a guiding vision for our modern world.

\section{REFERENCES}

Crafts, N. (2011). The Marshall Plan: A reality check. University of Warwick Working Paper Series, 49, 2011.

De Long, B., \& Eichengreen, B. (1991). The Marshall Plan: History's most successful structural adjustment program.

Duignan, P., \& Gann, L. H. (1997). The Marshall Plan. Hoover Digest, 4, 1 .

Gubin, E. (1948). How to do business under the Marshall Plan. Kiplinger Magazine, 5, 5-16.

Hitchens, H. (1968). Influences on the congressional decision to pass the Marshall Plan. Western Political Quarterly, 21, 51-68. doi: $10.2307 / 446512$

Hogan, M. (1987). The Marshall Plan. New York: Press Syndicate of The University of Cambridge. doi:10.1017/CBO9780511583728

Kindleberger, C. (1968). The Marshall Plan and the cold war. International Journal, 23, 369-382.

Mallalieu, W. (1958). Origins of the Marshall Plan: A study in policy formulation and national leadership. Political Science Quarterly, 3, 481-504. doi:10.2307/2146027

Marshall, G. (1947). Commencement speech. Cambridge, MA: Harvard University.

Truman, H. (1947). Address before joint session of congress. Washington DC. 